\title{
HOW BLOOD GLUCOSE EFFECT ON THE LIKLINESS OF PINEAPPLE
}

\author{
Muhammad Imran Qadir \& Asma Rasheed*
}

Institute of Molecular Biology and Biotechnology, Bahauddin Zakariya University, Multan, Pakistan

\begin{abstract}
The objective of the immediate learning was to associate collaboration of blood sugar with likeness of pineapple.one twenty learners took part in this study. Learners of molecular Biology and Biotechnology Bahauddin Zakariya University, Multan, Pakistan. The objective of the immediate research was to associate with communication of blood glucose level with likeness of pineapple. Total number of scholars joined in study was two hundred. An inquiry was providing them, in which they inquired about their likeness for pineapple and blood glucose level. Blood glucose level was uniform by blood glucose monitoring apparatus; A survey was done on the likeliness of pineapple and blood sugar level. A complete geometric investigation was done by using MS excel. Student t test was completed to determine the result of survey $\mathrm{P}<0.05$ value significant results. The current research indicate that students like to eat pineapple have more blood sugar then the other do not like to eat pineapple. Survey was provided them, asked about their likeness of pineapple and about their blood sugar. Current investigation show that scholars like to eat pineapple has less blood sugar then the other do not like to eat pineapple.
\end{abstract}

Keywords: Blood glucose, Pineapple likeliness, developed prediabetes, Brome lain breakdown 


\section{INTRODUCTION}

The blood glucose equal is the volume of glucose in the blood. Glucose is that arises from the diets we eat, and it's also designed and deposited intimate the body. It's the chief basis of energy for the cells of our body, and it's accepted to each cell concluded the bloodstream. A abstaining blood sugar a less amount then $100 \mathrm{mg} / \mathrm{dl} \quad 5.6 \mathrm{mmol} / \mathrm{L}$ is common. An abstaining blood glucose level since 100 to $125 \mathrm{mg} / \mathrm{dl} 5.6$ to $6.9 \mathrm{~mm} / \mathrm{L}$ is measured prediabetes the common blood sugar level verified while fasting aimed at nondiabetics, must be between 3.9 and 7.1 mole 70 to $130 \mathrm{mg} / \mathrm{dl}$ The mean conventional blood sugar level in humans is around $5.5 \mathrm{mmol} / \mathrm{L} 100 \mathrm{mg} / \mathrm{dll}$ however; this level alters through the day. Here is a blood glucose level. It is the ideal range that carefully provides the body with passable amount of energy. For the normal person, it is 70 to $105 \mathrm{mg} / \mathrm{dl}$ in a abstaining state. Even in high giant common blood glucose levels may persuade brain reduction a fasting blood glucose level of $10.0 \mathrm{mmol} / \mathrm{l} 180 \mathrm{mg} / \mathrm{dl}$. or complex means a individual has diabetes and at a close of 6.1 mole/l person is measured to high developed prediabetes or to have an reduced blood glucose level.

Pineapple is a eatable multiple fruit containing of merged berries, pineapple stand steamy fruit that are amusing in vitamins, enzymes and antioxidants. Pineapple is more lovely fruit. Energy of pineapple deceits in its vitamins and digestibility, pineapple contains $94 \%$ carbohydrate; have that mind if you are happening a low-carb diet. Pineapple supports decrease the danger of macular degeneration, sap from immature pineapple basis simple vomiting. Brome lain breakdown is related with a low rate of opposing reactions, counting diarrhea, extra menstrual flow, nausea, skin reckless, and vomiting. Inflammation of the mouth and cheeks. Pineapple healthiness benefits, maintenance immune system pineapple basis of vitamins and minerals,

The objective of the immediate research was to associate with communication of blood glucose level with likeness of pineapple.

\section{MATERIALS AND METHOD}

Total number of scholars joined in study was two hundred. An inquiry was providing them, in which they inquired about their likeness for pineapple and blood glucose level. Blood glucose level was uniform by blood glucose monitoring apparatus,

\section{Project Design}

A survey was done on the likeliness of pineapple and blood sugar level.

\section{Statistical study}

A complete geometric investigation was done by using MS excel. Student $\dagger$ test was completed to determine the result of survey $\mathrm{P}<0.05$ value significant results.

\section{RESULT AND DISCUSSION}


Interaction of blood sugar with pineapple likeness is specified in table 1: the learner's blood sugar $92.71 \pm 8.53$ likes to eat pineapple. And blood glucose
92.62 \pm 7.47 does not like pineapple. In the same way do not like pineapple normal blood glucose 9.46 7.47 calculated respectively.

Table 1: Contact of blood sugar (Mean \pm SD) with pineapple likeness

\begin{tabular}{|c|c|c|c|}
\hline Blood sugar & Pineapple likeness & $\begin{array}{l}\text { Pineapple } \\
\text { dislikeness }\end{array}$ & $p$-value \\
\hline Female & $92.71 \pm 8.53$ & $92.62 \pm 7.47$ & 0.95 \\
\hline Male & $91.5 \pm 9.46$ & $92.31 \pm 7.02$ & 0.72 \\
\hline Male and female & $92.24 \pm 8.24$ & $95.1 \pm 7.84$ & 0.16 \\
\hline
\end{tabular}

Census based studies has been important results in present investigation

\section{Conclusion}

The current research indicate that students like to eat pineapple have more blood sugar then the other do not like to eat pineapple.

\section{REFERENCES}

Qadir MI, Malik SA (2010) Comparison of alterations in red blood cell count and alterations in hemoglobin concentration in patients suffering from rectal carcinoma undergoing 5-fluorouracil and folic acid therapy. Pharmacologyonline, NI 3: 240243.

Qadir MI, Noor A (2018) Anemias. Rare \& Uncommon Diseases. Cambridge Scholars Publishing. Newcastle, England. ISBN: 9781-5275-1807-0.
Qadir MI, Javid A (2018) Awareness about Crohn's Disease in biotechnology students.

Glo Adv Res J Med Medical Sci, 7(3): 062064.

Qadir MI, Saleem A (2018) Awareness about ischemic heart disease in university biotechnology students. Glo Adv Res J Med Medical Sci, 7(3): 059-061.

Qadir MI, Ishfaq S (2018) Awareness about hypertension in biology students. Int J Mod Pharma Res, 7(2): 08-10.

Qadir MI, Mehwish (2018) Awareness about psoriasis disease. Int J Mod Pharma Res, 7(2): 17-18.

Qadir MI, Shahzad R (2018) Awareness about obesity in postgraduate students of biotechnology. Int J Mod Pharma Res, 7(2): 14-16. 
Qadir MI, Rizvi M (2018) Awareness about thalassemia in post graduate students. MOJ Lymphology \& Phlebology, 2(1): 1416.

Qadir MI, Ghalia BA (2018) Awareness survey about colorectal cancer in students of M. Phil Biotechnology at Bahauddin Zakariya University, Multan, Pakistan. Nov Appro in Can Study, 1(3): NACS.000514.2018.

Qadir MI, Saba G (2018) Awareness about intestinal cancer in university student. Nov
Appro in Can Study, 1(3): NACS.000515.2018.

Kannel WB, McGee DL: Diabetes and cardiovascular disease: the Framingham Study. J A M A241:2035-2038, 19792.

Stamler J, Va C c a ro O, Neaton JD, We n tw o rth D: Diabetes, other risk factors, and 12-year cardiovascular mortality for men $\mathrm{s}$ $c$ reened in the Multiple Risk Factor Intervention Trial. Diabetes Care 1 6:434444,1993 